\title{
KOGNITIVNI POREMEĆAJI \\ I DEMENCIJA KOD \\ BOLESNIKA NA \\ HEMODIJALIZI
}

\section{Miloš Glišićc \\ Zoran Kovačević ${ }^{1,2}$ \\ Sara Dodić ${ }^{3}$ \\ Maja Đerić Jeremić ${ }^{4}$ \\ Danijela Đerićs \\ Maja Sazdanović ${ }^{1}$ \\ Tatjana Lazarević ${ }^{2}$}

1 Fakultet medicinskih nauka

Kragujevac,

Kragujevac, Srbija

2 Klinički centar Kragujevac,

Kragujevac, Srbija

3 Klinika za psihijatriju,

Univerzitetski klinički centar Srbije,

Beograd, Srbija

4 Klinika za psihijatrijske bolesti

"Dr Laza Lazarević",

Beograd, Srbija

5 Klinički centar Niš, Niš, Srbija

doi: $10.5937 /$ engrami43-32808

prispelo: 18.06.2021.

prihvaćeno: 08.09.2021.

objavljeno onlajn: 08.09.2021.

\section{Sažetak}

Kognitivni poremećaji su učestali problem u svetu i značajno opterećuju život individue, njene okoline i zdravstveni sistem. Uključuju izmene u pamćenju, govoru, orijentaciji, rasuđivanju, pažnji ili egzekutivnim funkcijama. Pacijenti na hemodijalizi su u povećanom riziku od kognitivnog propadanja i razvoja demencije. Sam tok i priroda hronične bubrežne insuficijencije predstavljaju faktore rizika za kognitivno propadanje. Pored toga pacijenti na hemodijalizi su izloženi čestim hemodinamskim stresovima koji utiču na cerebralnu perfuziju na koje su posebno vunerabilni usled čestih komorbiditeta 
koji nose kardiovaskularni rizik. Takođe kod ove populacije su česte metaboličke abnormalnosti, poremećaji acido-bazne ravnoteže, disbalans vode i elektrolita, pojava inflamacije i oksidativnog stresa i nakupljanje toksičnih materija koji deluju kao faktori rizika za poremećaje kognicije. Adekvatno kognitivno funkcionisanje ovih pacijenata je bitno kako bi oni bili sposobni da vode računa o svom zdravlju i usvajaju medicinske savete, i kako bi imali što bolji kvalitet života. Iz tih razloga veoma je bitna rana detekcija faktora koji dovode do kognitivne disfunkcije kod ove populacije i blagovremena intervencija kako bi se ovi faktori rizika ublažili.

Ključne reči: demencija, kognitivni poremećaji, hemodijaliza

\section{IZJAVA O KONFLIKTU INTERESA}

Ne postoji konflikt interesa.

\section{UVOD}

Neurokognitivni poremećaji, posebno demencije, imaju ozbiljne posledice po individue, njihove porodice, zdravstveni sistem i ekonomiju. U visokorazvijenim zemljama, prevalencija demencije kod onih starijih od 65 godina je 5 do $10 \%{ }^{[1]}$.

Pad kognitivnih sposobnosti, bilo u domenu memorije, bilo i domenu neke druge kognitivne funkcije, najčešće se vezuje za proces starenja, međutim bitno je napraviti distinkciju između normalnog i patološkog starenja ${ }^{[2]}$. Demencija je stanje perzistentne i progresivne kognitivne disfunkcije koja se katakteriše pogoršanjem pamćenja i barem još jedne kognitivne funkcije koje uključuju govor, orijentaciju, rasuđivanje, pažnju ili egzekutivne funkcije u toj meri da narušavaju svakodnevno funkcionisanje pacijenta i njegovu nezavisnost. Blagi kognitivni poremećaj je entitet koji je uveden da opiše kognitivnu deterioraciju koja nadmašuje normalan proces starenja, ali ne ispunjava kriterijume za demenciju i ne utiče na svakodnevne aktivnosti individue. Populacija sa blagim kognitivnim poremećajem je u povećanom riziku za razvoj demencije ${ }^{[3,4]}$.

Hronična bubrežna insuficijencija (HBI) obuhvata heterogene nefrološke poremećaje koji dovode do oštećenja strukture i funkcije bubrega koji traju duže od 3 meseca. Iako je prevalenciju teško utvrditi, smatra se da je ona negde 
oko $11 \%$ u razvijenim zemljama kao što su SAD i Australija. Incidencija, prevalencija i progresija bolesti varira između etničkih i socijalnih klasa, međutim smatra se da osobe koje žive u lošijim socio-ekonomskim uslovima imaju oko $60 \%$ veću verovatnoću da obole od hronične bubrežne insuficijencije ${ }^{[5]}$.

U razvijenim zemljama razvoj hronične bubrežne bolesti povezan je sa starijom životnom dobi, dijabetesom, hipertenzijom, gojaznošću i kardiovaskularnim bolestima, sa dijabetesnom glomerulosklerozom i hipertenzivnom nefrosklerozom kao najčešćim pretpostavljenim patološkim entitetima. Sa druge strane, u zemljama u razvoju učestali uzroci HBI takođe uključuju i glomerularne i tubulointestinalne bolesti kao posledice infekcija i izloženosti drogama i toksinima ${ }^{[6]}$.

Imajući u vidu da su faktori vezani za nastanak HBI često zajednički za kognitivne poremećaje i demencije, kao i da HBI sama po sebi može biti faktor koji doprinosti nastanku psihijatrijsko-psiholoških izmena u oblasti kognitivnog funkcionisanja neophodna je posebna evalucija ovih grupa psihijatrijskih poremećaja u okviru $\mathrm{HBI}^{[7,8]}$.

Posebno tešku formu HBI karakteriše glomerularna filtracija (GFR) čija vrednost iznosi manje od $15 \mathrm{ml} / \mathrm{mi}$ $\mathrm{n} / 1.73 \mathrm{~m} 2$. Ovo stanje zahteva neku od metoda zamene bubrežne funkcije, kao što je hemodijaliza ili transplantacija bubrega, kako bi se eliminisali endogeni i egzogeni toksini i održala homeostaza tečnosti i elektrolita i acido-bazna ravnoteža [6]. Upravo ovo stanje može se odlikovati posebnim rizikom od pojave kognitivnih izmena usled dejstva različitih bioloških faktora na centralni nervni sistem.

Zbog toga ne čudi prevalencija kognitivnih poremećaja među bolesnicima sa završnom fazom bubrežne bolesti koja od 16 do $38 \%$ u zavisnosti od uzorka [9]. Upravo iz tog razloga je važno naglasiti da pacijenti na hemodijalizi pripadaju izuzetno vulnerabilnoj grupi kada su u pitanju kognitivni poremećaji i demencija te da zahtevaju posebnu pažnju psihijatrijske javnosti, detaljnu evaluaciju kognicije i ukoliko je potrebno pravovremeni i adekvatan terapijski pristup i tretman. Zbog toga je cilj ovog rada da da pregled osobenosti, izazova i nekih rešenja nastalih u okviru pojave kognitivnih izmena kod pacijenata na hemodijalizi kroz celine koje uključuju kliničke osnove bolesti, specifičnosti kognitivnih poremećaja i demencija kod pacijenata na hemodijalizi, specifičnost diagnostičkih procedura i značaj ranih intervencija kod ovih pacijenata.

\section{KLINIČKA OSNOVA BOLESTI}

Kako bubrežna bolest napreduje, bubrežna funkcija postaje sve manje efikasna i u organizmu se nakupljaju supstance, poznate kao uremični toksini, koje 
imaju negativan biološki uticaj. Uremični toksini doprinose inflamaciji, imunskoj disfunkciji, vaskularnim bolestima, disfunkciji trombocita i povećanom riziku od krvarenja, poremećajima gastrointestinalne bakteriološke mikroflore, poremećajima metabolizma lekova, kao i progresiji hronične bubrežne insuficijencije. Usled poremećaja endokrinih i ekskretornih funkcija bubrega, homeostaze vode i elektrolita, narušavanja acido-baznog statusa, kao i nakupljanja toksičnih materija u organizmu, posledice hronične bubrežne insuficijencije javljaju se na svim sistemima organa pa se javljaju simptomi kao što su bledilo usled anemije, hipertenzija, kratkoća daha, svrab i grčevi, anoreksija i zadah, oligurija, anurija, proteinurija, hematurija, periferni edemi i kognitivne prome$n e^{[5]}$.

Postoje brojni faktori rizika koji se mogu smatrati zajedničkim uzrocima kognitivnih poremećaja i hronične bubrežne insuficijencije kao što su hipertenzija i dijabetes melitus. Pored toga pacijenti sa terminalnom fazom bubežne bolesti, usled brojnih metaboličkih i endokrinih poremećaja, su u povećanom riziku od cerebrovaskularnih bolesti i šloga koje dovode do poremećaja i na kognitivnom polju. Takođe sam proces hemodijalize nosi svoje rizike za razvoj cerebrovaskularnih događaja koji mogu dovesti do kognitivnih izmena. Kako pad kognitivnih sposobnosti otežava pacijentima da vode računa o svom zdravlju i usvajaju medicinske savete, veoma je važno prepoznati faktore rizika kod ove grupe pacijenata na koje se može uticati u cilju očuvanja kognitivnih funkcija ${ }^{[7,8,10]}$.

\section{KOGNITIVNI POREMEĆAJI I HEMODIJALIZA}

Studije su pokazale da je veća prevalencija kognitivnog nedostatka kod pacijenata na hemodijalizi u poređenju sa opštom populacijom, a posledice toga su značajne i obuhvataju povećane troškove nege, povećan mortalitet i češće hospitalizacije $^{[11]}$. Ova populacija ima 2 do 7 puta veću učestalost javljanja kognitivnih poremećaja i demencije u poređenju sa opštom populacijom. Posebno je važno naglasiti da veliki broj (30-55\%) bolesnika na hemodijalizi, starijih od 75 godina, ima kognitivni poremećaj. Prevalencija kognitivnih poremećaja među mladim ili sredovečnim bolesnicima na hemodijalizi se kreće od $10-30 \%{ }^{[9]}$. Za svakih $10 \mathrm{ml}$ pada glomerularne filtracije ispod $60 \mathrm{ml} / \mathrm{min} / 1.73 \mathrm{~m} 2$ rizik od kognitivne insuficijencije raste za $11 \%^{[10]}$.

$\mathrm{Na}$ osnovu ekstenzivne studije $\mathrm{Oh}$ i sar. (2019) koja je metanalitickim pristupom obuhvatila 39 studija koje su se bavile kognitivnim propadanjem kod pacijenata na dijalizi pokazano je da faktori kao što su ženski pol, godine, nivo hemoglobina, cerebrovaskularna oboljenja (npr.šlog), svakodnevne aktiv- 
nosti, depresija, nesanica i bol mogu u velikoj meri da doprinesu kognitivnim nedostacima kod pacijenata na dijalizi ${ }^{[7]}$. Treba napomenuti da je kod pacijenata na hemodijalizi česta pojava anemije, usled prirodnog toka bolesti i smanjene produkcije eritropoetina, što može dovesti do moždane hipoksije i opadanja kognitivnih sposobnosti. Takođe, kompenzatornim mehanizmima kao odgovora na anemiju, dolazi do povećanog cerebralnog protoka krvi, što povećava dotok uremičnih toksina do mozga ${ }^{[12]}$.

Kao glavni uzroci razvoja hronične bubreže insuficijencije se smatraju dijabetes melitus tip 2 i hipertenzija. U opštoj populaciji ova stanja su takođe povezana i sa razvojem kognitivne disfunkcije. Hipertenzija povećava rizik za razvoj bolesti malih krvnih sudova i šloga, a dijabetes dovodi do vaskularnih i metaboličkih poremećaja, oba dovodeći na svoj način do kognitivne disfunkcije. Starija životna dob, nivo homocisteina u krvi i hiperlipidemija takođe su faktori rizika koji povezuju HBI i kognitivnu disfunkciju. Istovremeno, same posledice hronične bubreže insuficijencije kao što su anemija, hipoksemija, uremični toksini, oksidativni stres i inflamacija predstavljaju faktore rizika za razvoj kognitivnih poremećaja ${ }^{[7,8,10]}$. Međutim postavlja se pitanje kakav je uticaj samog procesa hemodijalize na kognitivni status pacijenata u poslednjem stadijumu bubrežne bolesti.

Post i saradnici (2012) u svojoj studiji pokazali su da su pacijenti na hemodializi u povećanom riziku od kognitivnih ispada u poređenju sa kontrolnom grupom sličnih po godinama i komorbiditetima kada se umanje uticaji prethodnih neuroloških događaja, uremije i kardovaskularnih faktora rizika. Ovo možda ukazuje da hronična bubrežna insuficijencija i proces hemodijalize možda deluju kao nezavisni faktori koji doprinose većoj prevalenciji kognitivne disfunkcije u ovoj populaciji ${ }^{[11]}$.

Vodeća hipoteza je da moždana ishemija tokom hemodijalize doprinosi ubrzanom kognitivnom propadanju. Tokom hemodijalize volumen krvi se uklanja iz pacijentovog tela i filtrira kroz semipermeabilnu membranu. Ovo je postavljeno kao potecijalni faktor koji pogoršava kognitivne funkcije kroz hemodinamske nestabilnosti koje pogađaju cerebralnu perfuziju dovodeći do oštećenja organa. Ove hemodinamske nestabilnosti nastaju kao posledica hemodijalizom indukovanog kolebanja krvnog pritiska, a takođe i miokardne disfunkcije i vaskularne disfunkcije kao posledica inflamacije i oslobađanja endotoksina ${ }^{[13-17]}$. Takođe niži skorovi na Montreal Cognitive Assessment (MoCA) testiranju su povezani sa nižom regionalnom saturaciom kiseonikom što je verovatno posledica hemodinamskih stresova na koje su pacijenti na hemodijalizi posebno vunerabilni, usled brojnih komorbiditeta koji dovode do vaskularnih promena ${ }^{[19,20]}$. 
Pored cerebrovaskularnih patomehanizama, postoje vrlo snažne indicije da uremični toksini oštećuju kognitivne funkcije. Kod pacijenata sa HBI dolazi do nakupljanja jedinjenja koja imaju štetne posledice po organizam poznatih kao uremični toksini, koji deluju kao neurotoksini. Identifikovana su brojna jedinjenja koja bi mogli da deluju kao potencijalni neurotoksini kod pacijenata sa HBI kao što su $\beta 2$-mikroglobulin, indoksil sulfat, homocistein, mokraćna kiselina i paratireoidni hormon. Ova jedinjenja interaguju sa neurotransmiterima i oštećuju zidove krvnih sudova, što se negativno odražava na kognitivno funkcionisanje, dovodeći do uremične ecefalopatije. Čak i nakon iniciranja hemodijalize neke od ovih posledica ostaju trajne $e^{[8,21-23]}$.

U radu O'Lone i sar. (2016) obrađene su 42 studija koje su obuhvatile 3522 pacijenta sa hroničnom bubrežnom insuficijencijom. Pacijenti u poslednjoj fazi hronične bubrežne insuficijencije svakako vrlo često pokazuju kognitivno propadanje. Ipak, u ovom radu pokazano je da su pacijenti na hemodijalizi imali bolji kognitivni status u odnosu na pacijente sa terminalnom fazom bubrežne bolesti koji se nisu podvrgavali dijalizi u smislu pažnje i pamćenja. Ali, kao što se i očekivalo, ovi pacijenti imali su gore pamćenje u odnosu na standard za opštu populaciju ${ }^{[24]}$. Ovo ukazuje na značaj adekvatnog eliminisanja toksičnih materija iz krvi porcesom hemodijalize u cilju prevencije kognitivnog pada kao posledice uticaja neželjenih supstanci na organizam.

Dodatno, trajanje hemodijalize, hemoglobin, hematokrit, nedostatak eritropoetina, određena jedinjenja kao što su parathormon i jedinjenja koja sadrže aluminijum takođe su povezana sa razvojem kognitivnih poremećaja kod pacijenata na hemodijalizi ${ }^{[7]}$.

U skladu sa tim značajno je da pacijenti na hemodijalizi budu sagledani u celini, i držati pod kontrolom sve one faktore rizika koji mogu dovesti do poteškoća u kognitivnom funkcionisanju, a na koje se može uticati, kako bi se obezbedio što bolji kvalitet života pacijentima iz ove populacije.

\section{HEMODIJALIZA I DEMENCIJA}

Demencija je sindrom globalnog i progresivnog oštećenja stečenih kognitivnih sposobnosti, prouzrokovan organskom bolešću mozga, pri očuvanoj svesti, u kome su oštećene sposobnosti apstraktnog mišljenja, pamćenja, rasuđivanja, orjentacije i učenja. Oštećenje kognitivnih funkcija često je praćeno ili mu prethode narušena kontrola emocija, socijalnog ponašanja i nagona ${ }^{[12]}$.

Hronična bubrežna insuficijencija, koja dovodi do potrebe za hemodijalizom, i demencija dele brojne faktore rizika koje u osnovi vaskularnu etiopatogenezu kao što su hipertenzija i dija- 
betes ${ }^{[5,6,25]}$.

Prema prethodnim studijama rizik za demenciju raste kod pacijenata na dijalizi u poređenju sa opštom populacijom i tipovi demencija se razlikuju od onih u opštoj populaciji. Jednogodišnja incidenca multi-infarktne demencije kod starijih pacijenata na hemodijalizi 7.4 puta je veća nego u opštoj populaciji, pokazujući da pacijenti na hemodijalizi imaju tendenciju da manifestuju multi-infarktnu demenciju ${ }^{[26]}$.

Pokazano je da su stariji pacijenti na hemodijalizi u značajnom riziku da budu dijagnostikovani sa demencijom ili Alchajmerovom bolešću, a nosioci ove dijagnoze su povezani sa dvostruko većom smrtnošću ${ }^{[27]}$. Magdalene i sar. (2019) su pokazali da povećana kumulativna ekspozicija čestim intradialitičkim hipotenzijama je povezana sa višim rizikom početka demencije unutar 5 godina, napominjući da bi možda bolja kontrola krvnog pritiska tokom dijalize smanjila učestalost demencija kod ove grupe pacijenata ${ }^{[28]}$.

U studiji Haung i sar. (2008) pokazana je značajna povezanost hipoalbuminemije i demencije kod pacijenata na dijalizi. Autori napominju da bio ova povezanost možda ukazivala da nutritivni faktori više utiču na razvoj demencije kod pacijenata na dijalizi nego tradicionalni faktori rizika za vaskularne bolesti $^{[29]}$.

\section{DIJANOSTIČKI PRISTUP KOGNITIVNIM POREMECAJIMA I DEMENCIJI KOD PACIJENATA NA HEMODIJALIZI}

Dijagnostika kognitivnih poremećaja i demencija kod pacijenata sa HBI na hemodijalizi uključuje opšti dijagnostički pristup i specifičnosti vezane za prirodu komorbiditeta i sam tok bolesti.

Opšti dijagnostički pristup detekcije kognitivnog propadanja obuhata subjektivnu i objektivnu procenu. Subjektivna procena se sastoji iz razgovora sa pacijenatom i članovima porodice ili osobama iz najbliže okoline pacijenta u cilju dobijanja podataka koje su to promene primećenje i koji su aspekti pacijentovog života najviše zahvaćeni. Objektivna procena podrezumeva upotrebu neuropsihometrijskih skrining testova kao što su n Mini-Mental State Examination (MMSE), Montreal Cognitive Assessment (MoCA) ili MiniCog. Ovi testovi su obično dovoljno senzitivni za detekciju demencije, ali kod blažih kognitivnih poremećaja nisu uvek uspešni [30].

Specifični dijagnostički pristup podrazumeva upotrebu nestandardizovanih biohemijskih analiza koje bi mogle poslužiti kao potencijalni biomarkeri za detekciju kognitivnih poremećaja kod pacijenata na dijalizi, kao i diferencijalnu dijagnozu poremećaja koji su mogli biti uzrok kognitivnih abnormalnosti 
kod ove populacije.

Predloženi su i neki biomarkeri koji bi mogli poslužiti za prepoznavanje kognitivnih poremećaja kod pacijenata na hemodijalizi kao što su BDNF, TNF- $\alpha$ i IL-6, kao i broj trombocita u krvi ${ }^{[31,32]}$.

Mnogi faktori mogu dovesti do kognitivnog propadanja kod pacijenata na hemodijalizi, među kojima su metabolička enefalopatija, hiperkalcemija, hipofosfatemija, hipoglikemija, hiperosmolarnost, hiponatrijemija, uremija, intoksikacija elementima u tragu, nedostatak vitamina, intoksikacija lekovima, hipertenzivna enefalopatija, hemodinamska nestabilnost, strukturne lezije, cerebrovaskularni događaji i bolesti, neuropsihijatrijske bolesti itd. ${ }^{[12]}$. Prepoznavanje tačnog uzroka koji je doveo do promena u mentalnom statusu u domenu kognicije veoma je važno u cilju izbora pravovremene i adekvatne terapije i procedure koja bi omogućila reverziju simptoma ili sprečila dalju progresiju kognitivnog propadanja

U nedostatku specifičnih laboratorijskih testova za utvrđivanje demencije, njena dijagnoza se zasniva uglavnom na kliničkim kriterijumima koji podrazumevaju:

1) oštećenje memorije,

2) afazija i/ili apraksija, agnozija ili poremećaj egzekutivnih funkcija,

3) poremećaj funkcionisanja u socijalnom i profesionalnom domenu,

4) značajan pad sa prethodnog nivoa kognitivnog funkcionisanja ${ }^{[33]}$.

\section{ZNAČAJ RANIH INTERVENCIJA}

Rana detekcija i adekvatna intervencija za kognitivno propadanje kod pacijenata na hemodijalizi treba da bude sprovedena u cilju povećavanja sposobnosti brige o svom zdravlju i da se poveća kvalitet života kod ove grupe pacijenata $^{[7]}$.

Poremećaj elektrolita, deficit vitamina, intoksikacija lekovima, hipertenzivna encefalopatija, akutno trovanje elementima u tragu, kolebanje krvnog pritiska i anemija su česti faktori koji dovode do promena u mentalnom statusu pacijenata na hemodijalizi, posebno u kognitivnom domenu ${ }^{[7,20,22]}$. Ranim otkrivanjem i blagovremenom intervencijom ovih poremećaja mogli bi se preokrenuti štetni efekti koji su doveli do kognitivne disfunkcije, ili bar usporiti propadanje na kognitivnom planu. Iz tih razloga je veoma bitno pacijenta sagledati u celini, pratiti opšte somatsko stanje pacijenta, sprečiti kolebanje krvnog pritisaka, redovno sprovoditi laboratorijske analize i periodično obavljati kognitivne testove sve u cilju prevencije faktora rizika i blagovremene intervencije, koje bi ovim pacijentima otežali svakodnevno funkcionisanje i smanjile životni vek. 


\section{ZAKLJUČAK}

Kognitivni poremećaji, uključujući i demenciju su česti kod bolesnika na hemodijalizi i uslovljavaju manje povoljan tok bolesti. Terapija ima ograničenu vrednost kod bolesnika na hemodijalizi, ali drugi postupci u smislu poboljšanja kognitivnih sposobnosti mogu da umanje sam teret bolesti i poboljšaju njihov kvalitet života. Od najznačajnijh faktora izdvajaju se modifikacija vaskularnog rizika kao poželjna preventivna strategija, kao i modifikacija metaboličkih faktora rizika, uz adekvatnu nutritinu suplementaciju. Potrebne su dodatne studije o kognitivnim poremećajima i demenciji kod bolesnika na hemodijalizi kako bi se unapredila klinička praksa.
COGNITIVE

DISORDERS AND

DEMENTIA IN

PATIENTS ON

HEMODIALYSIS

\section{Milos Glisic ${ }^{1}$}

Zoran Kovacevic ${ }^{1,2}$

Sara Dodic ${ }^{3}$

Maja Djeric Jeremic ${ }^{4}$

Danijela Djeric ${ }^{5}$

Maja Sazdanovic ${ }^{1}$

Tatjana Lazrevic ${ }^{2}$

1 Faculty of medical sciences

Kragujevac, Kragujevac, Srbija

2 Clinical center Kragujevac,

Kragujevac, Srbija

3 Clinic for Psychiatry, University

Clinical Center of Serbia, Belgrade,

Serbia

4 Psychiatric clinic "Dr Laza

Lazarevic" Beograd

5 Clinical centerNis

doi: 10.5937/engrami43-32423

submitted: 2021/06/18

accepted: 2021/09/08

online published: 2021//09/08 


\section{Abstract}

Patients on hemodialysis are at increased risk of cognitive decline and the development of dementia. The course and nature of chronic renal failure are risk factors for cognitive decline. In addition, patients on hemodialysis are exposed to frequent hemodynamic stresses that affect cerebral perfusion to which they are particularly vulnerable due to frequent comorbidities that carry cardiovascular risk. Metabolic abnormalities, acid-base imbalances, water and electrolyte imbalances, inflammation and oxidative stress, and the accumulation of toxic substances that act as risk factors for cognition disorders are also common in this population. Adequate cognitive functioning of these patients is essential in order for them to be able to take care of their health and adopt medical advice, and to have the best possible quality of life. For these reasons, early detection of factors that lead to cognitive dysfunction in this population and right time intervention are very important to alleviate these risk factors.

Key words: dementia, cognitive disorders, hemodialysis

\section{LITERATURA / LITERATURE}

1. Hugo J, Ganguli M. Dementia and Cognitive Impairment: Epidemiology, Diagnosis, and Treatment. Clin Geriatr Med. 2014 Aug 1;30(3):421-42.

2. Portet $F$, Ousset PJ, Visser PJ, Frisoni GB, Nobili F, Scheltens P, et al. Mild cognitive impairment $(\mathrm{MCl})$ in medical practice: a critical review of the concept and new diagnostic procedure. Report of the $\mathrm{MCl}$ Working Group of the European Consortium on Alzheimer's Disease. J Neurol Neurosurg Psychiatry. 2006 Jun 1;77(6):714-8.

3. El, Gohary IE El, Sheshtawi HA, Mohamed MMA. Cognitive disorders in chronic kidney disease and hemodialysis patients. J Egypt Soc Nephrol Transplant. 2018;18(4):130.

4. Gesualdo GD, Duarte JG, Zazzetta MS, Kusumota L, Say KG, Pavarini SCI, et al. Cognitive impairment of patients with chronic renal disease on hemodialysis and its relationship with sociodemographic and clinical characteristics. Dement Neuropsychol. 2017 Jul 1;11(3):221-6.

5. Webster AC, Nagler E V., Morton RL, Masson P. Chronic Kidney Disease. Vol. 389, The Lancet. Lancet Publishing Group; 2017. p. 1238-52.

6. Levey AS, Coresh J. Chronic kidney disease. Vol. 379, The Lancet. Elsevier B.V.; 2012. p. 165-80.

7. Oh HS, Mo JA, Seo WS. Correlates of cognitive impairment in patients with chronic kidney failure on haemodialysis: Systematic review and meta-analysis. Vol. 75, Journal of Advanced Nursing. Blackwell Publishing Ltd; 2019. p. 962-78.

8. Hannan M, Phillips SA, Collins EG, Quinn L, Steffen A, Bronas UG. Kidney Disease 
and Cognitive Impairment in Older Adults: The State of the Science. J Clin Exerc Physiol. 2019 Jun 1;8(2):74-81.

9. Seliger SL, Siscovick DS, Stehman-Breen CO, Gillen DL, Fitzpatrick A, Bleyer A, et al. Moderate renal impairment and risk of dementia among older adults: The cardiovascular health cognition study. J Am Soc Nephrol. 2004 Jul;15(7):1904-11.

10. Tian X, Guo X, Xia X, Yu H, Li X, Jiang $A$, et al. The comparison of cognitive function and risk of dementia in CKD patients under peritoneal dialysis and hemodialysis: A PRISMA-compliant systematic review and meta-analysis. Vol. 98, Medicine (United States). Lippincott Williams and Wilkins; 2019.

11. Post JB, Morin KG, Sano M, Jegede AB, Langhoff $E$, Spungen AM. Increased presence of cognitive impairment in hemodialysis patients in the absence of neurological events. Am J Nephrol. 2012 Feb;35(2):120-6.

12. Pereira AA, Weiner DE, Scott T, Sarnak MJ. Cognitive function in dialysis patients [Internet]. Vol. 45, American Journal of Kidney Diseases. W.B. Saunders; 2005. p. 448-62.

13. Murray AM, Tupper DE, Knopman DS, Gilbertson DT, Pederson SL, Li S, et al. Cognitive impairment in hemodialysis patients is common. Neurology. 2006 Jul;67(2):216-23.

14. Marants R, Qirjazi E, Grant CJ, Lee TY, McIntyre CW. Renal perfusion during hemodialysis: Intradialytic blood flow decline and effects of dialysate cooling. J Am Soc Nephrol. 2019 Jun 1;30(6):108695.

15. Burton JO, Jefferies HJ, Selby NM, McIntyre CW. Hemodialysis-induced cardiac injury: Determinants and associated outcomes. Clin J Am Soc Nephrol. 2009 May 1;4(5):914-20.

16. 1Mcintyre CW. Recurrent Circulatory Stress: The Dark Side of Dialysis. Vol. 23, Seminars in Dialysis. Semin Dial; 2010. p. 449-51.

17. McIntyre CW, Burton JO, Selby NM, Leccisotti L, Korsheed S, Baker CSR, et al. Hemodialysis-induced cardiac dysfunction is associated with an acute reduction in global and segmental myocardial blood flow. Clin J Am Soc Nephrol. 2008 Jan;3(1):19-26.

18. Ibrahim M, Behairy M, El-Ashry M, Mostafa AE. Cardiovascular risk of circulating endotoxin level in prevalent hemodialysis patients. Egypt Hear J. 2018 Mar 1;70(1):27-33.

19. Kovarova L, Valerianova A, Kmentova T, Lachmanova J, Hladinova Z, Malik J. Low Cerebral Oxygenation Is Associated with Cognitive Impairment in Chronic Hemodialysis Patients. Nephron. 2018 May 1;139(2):113-9.

20. Wolfgram DF. Intradialytic cerebral hypoperfusion as mechanism for cognitive impairment in patients on hemodialysis. Vol. 30, Journal of the American Society of Nephrology. American Society of Nephrology; 2019. p. 2052-8.

21. Duranton F, Cohen G, De Smet R, Rodriguez M, Jankowski J, Vanholder R, et al. Normal and pathologic concentrations of uremic toxins. J Am Soc Nephrol. 2012 Jul 1;23(7):1258-70.

22. Mahoney CA, Arieff Al. Uremic Encephalopathies: Clinical, Biochemical, and Experimental Features. Vol. 2, American Journal of Kidney Diseases. Am J Kidney Dis; 1982. p. 324-36.

23. Seifter JL, Samuels MA. Uremic encephalopathy and other brain disorders 
associated with renal failure. Semin Neurol. 2011;31(2):139-43.

24. O'Lone E, Connors M, Masson P, Wu S, Kelly PJ, Gillespie D, et al. Cognition in people with end-stage kidney disease treated with hemodialysis: A systematic review and meta-analysis. Am J Kidney Dis. 2016 Jun 1;67(6):925-35.

25. Takeda S, Rakugi H, Morishita R. Roles of vascular risk factors in the pathogenesis of dementia. Vol. 43, Hypertension Research. Springer Nature; 2020. p. 162-7.

26. Fukunishi I, Kitaoka T, Shirai T, Kino K, Kanematsu E, Sato Y. Psychiatric disorders among patients undergoing hemodialysis therapy. Nephron. 2002;91(2):344-7.

27. McAdams-Demarco MA, Daubresse M, Bae S, Gross AL, Carlson MC, Segev DL. Dementia, Alzheimer's disease, and mortality after hemodialysis initiation. Clin J Am Soc Nephrol. 2018 Sep 7;13(9):1339-47.

28. Assimon MM, Wang L, Flythe JE. Cumulative Exposure to\&nbsp;Frequent Intradialytic Hypotension Associates With New-Onset Dementia Among Elderly Hemodialysis Patients. 2019

29. Huang YC, Kuo YW, Lee TH, Lee M, Hsiao $\mathrm{MC}$, Wang $\mathrm{CL}$, et al. Hypoalbuminemia and Not Hyperhomocysteinemia as a Risk Factor for Dementia in Hemodialysis Patients. J Ren Nutr. 2008 Jul 1;18(4):347-54.

30. Hugo J, Ganguli M. Dementia and Cognitive Impairment. Epidemiology, Diagnosis, and Treatment. Vol. 30, Clinics in Geriatric Medicine. W.B. Saunders; 2014. p. 421-42.

31. Shin SJ, Yoon HE, Chung S, Kim YG, Kim DJ. Plasma brain-derived neurotrophic factor in hemodialysis patients. Int J Med
Sci. 2012 Oct 24;9(9):772-7.

32. Zhu B, Jin LN, Shen JQ, Liu JF, Jiang RY, Yang L, et al. Differential expression of serum biomarkers in hemodialysis patients with mild cognitive decline: $\mathrm{A}$ prospective single-center cohort study. Sci Rep. 2018 Dec 1;8(1):12250.

33. Petersen RC. Mild cognitive impairment as a diagnostic entity. In: Journal of Internal Medicine. John Wiley \& Sons, Ltd; 2004. p. 183-94.
Zoran Kovačević,

Fakultet medicinskih nauka

Kragujevac,

Kragujevac, Srbija

kovacevic.zoran@icloud.com 